\title{
SPLENOMEGALY IN RELATION TO SCHISTOSOMA MANSONI EGG COUNTS: A POPULATION BASED STUDY (1)
}

\author{
Maria Fernanda Furtado de Lima e cosTA (2), R. S. ROCHA (3) \& Naftale KA'TZ (3)
}

\section{S U M M A R Y}

A cross: sectional survey on schistosomiasis was done in Comercinho (Minas Gerais State, Brazil), a town with 1474 inhabitants. Stool (Kato-Katz method) and physical examinations were done on $90 \%$ of the population and on $84 \%$ of the individuals over 2 years of age, respectively. The ecological and individual (case-control) analysis were used to investigate the relation between splenomegaly and S. mansoni egg counts in different age groups. In the ecological analysis there was a clearly correspondence between higher geometric mean of eggs and higher percentage of splenomegaly in the age groups 5-9 and 10-12 years. In the individual analysis it was found that only in the youngest individuals (5-8 or 5-9 years old) the splenomegaly was related with higher mean egg counts in the feces, having been a tendency to the decrease of excretion of eggs in patients with splenomegaly as the age increased. These results strongly suggest that the ecological data are better indicator of the severity of schistosomiasis in endemic areas, as the decrease of the egg excretion in patients with splenomegaly may be a confounding variable for the individual analysis.

KEY WORDS: Human schistosomiasis - Splenomegaly; Egg counts - S. mansoni

\section{N T ROD U G T IO N}

Several epidemiologic aspects of schistosomiasis have been investigated in Comercinho (Brazil). The results from these studies indicate that the severity of schistosomiasis is related with the intensity of water contact and with the intensity of infecion by $\mathbf{S}$. mansoni $\left.\right|^{9,0}$. In fact, the absence of piped water in the house and the intense and/or daily contacts with waters presumably infected were the greatest risk factors for development of the splenomegaly in individuals under 15 years of age $\left.\right|^{10}$. In the same way, the decrease of the geometric mean of S. mansoni eggs observed in the cen. tral zone of Comercinho between 1974 and 1981 was followed by the decrease of the percentage of splenomegaly; in the environs of the town, where the mean egg count did not change, the percentage of splenomegaly did not change eighter \%. Nevertheless, a case-control study carried out in the town showed a strong association between higher egg counts and hepatomegaly in individuals under 15 years of age, but not in relation to splenomegaly ${ }^{6}$.

To understand this apparent paradox, from 1974 to 1981 'we followed-up the clinical evolution in relation to the evolution of egg count in 90 children (0-14 years old) from Comercinho ${ }^{8}$. This study showed that the children that developed splenomegaly presented a relative di. minution of the number of $\mathbf{S}$. mansoni eggs in the stools seven years later, when compared to

(1) Sponsored by the Conselho Nacional de Desenvolvimento Cientifico e Tecnológico (CNPq) and by the Financiadora de Estudos e Projetos (FINEP)

(2) Departamento de Medicina Preventiva e Social da Universidade Federal de Minas Gerais. 30.130 Belo Horizonte, Minas Gerais, Brazil .

(3) Centro de Pesquisas "René Rachou" da Fundação Oswaldo Cruz, Belo Horizonte, Minas Gerais, Brazil 
COSTA, M. F. F. de L. e; ROCHA, R. S. \& KATZ, N. - Splenomegaly in relation to Schistosoma mansoni egg counts: a population based study. Rev. Inst. Med. trop. São Paulo, 28:389 394, 1986.

the ones that remained without splenomegaly. Unfortunately, this result must be applied to other people with caution because $70 \%$ of the 349 children that participated of the first examination were lost due to migration seven years later.

In a recent paper, BARRETO et al..$^{2}$ suggested that grouping the individuals in small intervals of age, such as 5-8, 9-12 and 13.16 years, permit "to examine the results (of the egg counts) as longitudinal-like data without the confounding influence of age". In the present study we adopted the division suggested by these authors, analysing the total population ( $\equiv 5$ years old) from Comercinho, aiming to test the hypothesis that only early in life (or in the earlier stages of the increase of the spleen) it is possible to detect higher egg counts in individuals with splenomegaly.

\section{MATERIALS AND METHODS}

This investigation was carried out in Comercinho, a town with 1474 inhabitants situated in the Southeast of Brazil (Minas Gerais State), where the population in the center and in the environs are socially different. In the environs, $81 \%$ of the chief of family are manual workers and only $7 \%$ of the houses have piped water supply, while in the center $43 \%$ of the heads of family are owners or skilled workers, and $44 \%$ of the dwellings have piped water supply. There are no cases of malaria or visceral leishmaniasis in the area and the intermediate host is Biomphalaria glabrata. Further details are in COSTA et al. ${ }^{7}$.

Stools were examinated by the KATO-KATZ method ${ }^{14}$ and all by the same technician. Two slides of the fecal samples of each individual were examined and the mean data was considered the number of $\mathbf{S}$. mansoni eggs per gramme. Those with $\mathbf{S}$. mansoni eggs in the examination were considered positives.

Physical examination was performed-by only one physician ignoring stool data. Individuals were examined in decubitus dorsales and in right lateral decubitus. If the spleens were palpable below the costal margin when subjects held their breath, the organ was considered to be enlarged. The children under 2 years of age were excluded of this examination as none was positive 6.7 .
Intradermal test 19 was done in individuals without S. mansoni eggs in the stools and who had never been treated with schistosomicides. Individuals that had never been treated and with negative intradermal test (papule $<1 \mathrm{~cm}^{2}$ ) were classified as negative-1; those with report of previous treatment or with positive intradermal test (papule $\geqslant 1 \mathrm{~cm}^{2}$ ) were considered as negative -26 .

\section{Statistical analysis}

The STUDENT's t test was used for differences between the means, and the $\mathrm{X}^{2}$ test was applied for analyses differences among the frequencies ${ }^{23}$. The minimum level considered sig. nificant was $95 \%$.

\section{RESULTS}

Stool examinations were done on 1329 in. dividuals $(90.2 \%$ of the total population), and $70.4 \%$ presented $\mathbf{S}$. mansoni eggs in the examination. Of the individuals with no $\mathbf{S}$. manso. ni eggs, 145 were classified as negative-2 and 155 as negative-1. $92.2 \%$ (863) of the positives and $91.2 \%$ (301) of the negatives over 2 years of age were physically examinated. The percentages of splenomegaly were: $6.8,7.0$ and $0.0 \%$ in the positive, negative-2 and negative-1 individuals, respectively. Fifty seven positive individuals ( 50 over 15 years of age) had been previously treated with schistosomicides and presented smaller egg counts in the stools than the never treated ones (geometric mean = $186.8 \pm 4.3$ and $343.2 \pm 4.8 \mathrm{epg}$, respectively); the treated cases were excluded from the analysis on TABLES II and III. The proportion of positives that had been treated did not differ between those with or without splenomegaly.

TABLE I and Fig. 1 shows the geometric mean of eggs and the percentages of spleno. megaly in the center and in the town environs, according to the age. The mean egg counts were significantly higher in all groups over 5 years of age that lived in the environs when compared to those from the town centre, while the percentages of splenomegaly were higher in the groups with 5-9 and 10-14 years of age.

TABLE II shows the individuals levels of egg counts in relation to the splenomegaly in three age groups. The only statistically significant difference was in the 5-9 age group, 'where the geometric mean of eggs was higher in the cases with splenomegaly. 
COSTA, M. F. F. de L. e; ROCHA, R. S. \& KATZ, N. - Splenomegaly in relation to Schistosoma mansoni egg counts: a population based study. Rev. Inst. Med. trop. São Paulo, 28:389-394, 1986.

T. A B L E I

Geometric mean of egg and percentage of splenomegaly in the centre and in the town environs, according to the age

\begin{tabular}{|c|c|c|c|c|c|c|c|c|c|c|c|c|}
\hline \multirow{2}{*}{\multicolumn{2}{|c|}{$\begin{array}{l}\text { Age } \\
\text { groups } \\
\text { (years) }\end{array}$}} & \multicolumn{3}{|c|}{ (N. positives) } & \multicolumn{4}{|c|}{ Geometric mean of eggs \pm SD } & \multicolumn{4}{|c|}{ (N.० examinated) $\%$ with splenomegaly } \\
\hline & & \multicolumn{3}{|c|}{ Environs* } & \multicolumn{4}{|c|}{ Center } & \multicolumn{2}{|c|}{ Environs +} & \multicolumn{2}{|c|}{ Center } \\
\hline & -4 & (28) & 357.7 & \pm 5.2 & (16) & 172.9 & \pm & 5.0 & (28) & 0.0 & (16) & 0.0 \\
\hline & -8 & (71) & 851.9 & $\pm 5 . \theta^{*}$ & (108) & 234.3 & \pm & 4.6 & (71) & $16.9+$ & (108) & 0.0 \\
\hline 10 & -14 & (97) & 967.1 & $\pm 4.9^{*}$ & (147) & 327.6 & \pm & 4.2 & (94) & $14.5+$ & (138) & 4.4 \\
\hline & -19 & $(50)$ & 821.1 & $\pm 3.2^{*}$ & (85) & 332.3 & \pm & 4.8 & (47) & 8.5 & ( 78$)$ & 5.1 \\
\hline & $\Longrightarrow 20$ & (126) & 302.0 & $\pm 3.9^{*}$ & (208) & 166.0 & \pm & 3.1 & (100) & 9.0 & (183) & 5.5 \\
\hline
\end{tabular}

*: Statistically significant differences between center and environns (STUDENT's $t$ test)

f: Statistically significant differences between center and environs ( $x^{2}$ test); the 0.4 group was excluded

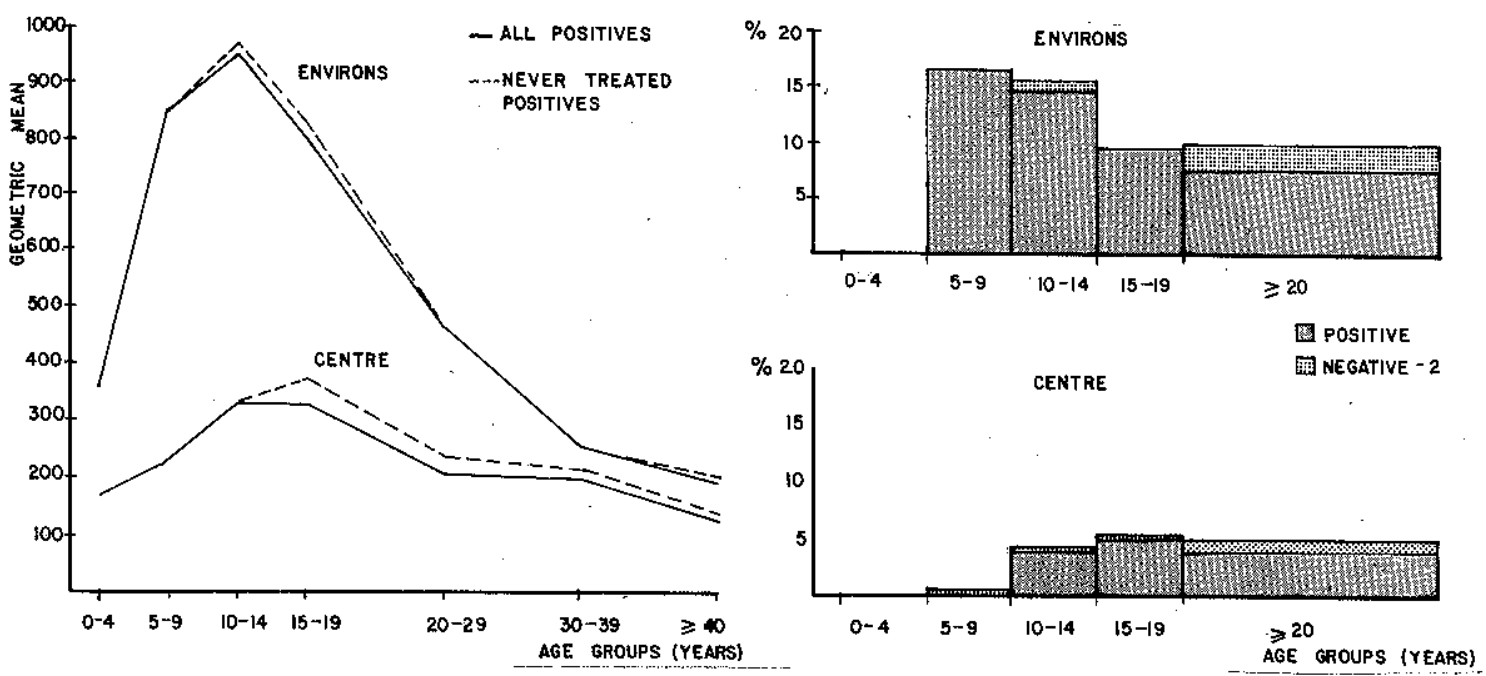

Fig. 1 - Geometric mean of eggs and percentage of splenomegaly in the centre and in the town environs, according to the age

T A B I E II

Schistosoma mansoni egg counts in individuals with and without splenomegaly, according to three age groups

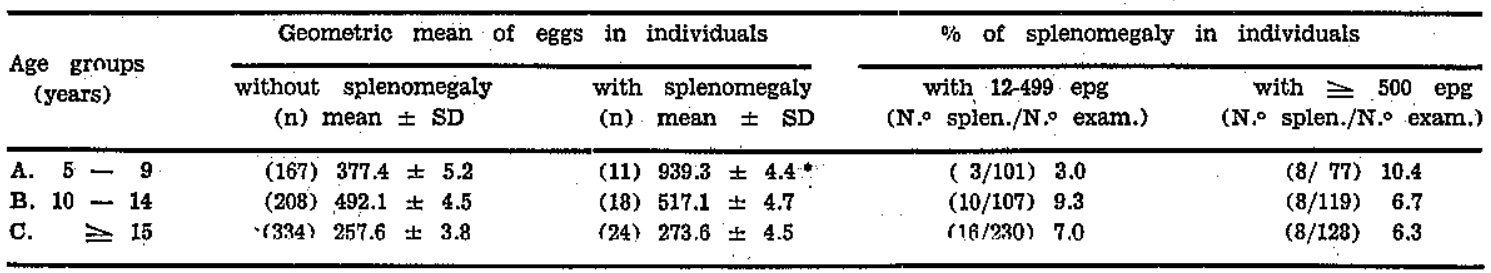

*: Statistically significant difference $(\mathrm{p}<0.05)$ epg: eggs per gram.

TABLE III shows the individual levels of egg counts in relation to the splenomegaly in four age groups. The geometric mean of eggs was significantly higher in the 5.8 years old in-

$$
\begin{aligned}
& t_{A}=1.96 ; 176 \mathrm{df} * ; \mathrm{x}_{\mathrm{A}}^{4}=2.96 ; 1 \mathrm{df} \\
& \mathrm{t}_{\mathrm{B}}=0.13 ; 224 \mathrm{df} ; \mathrm{x}_{\mathrm{B}}^{2}=0.23 ; 1 \mathrm{df} \\
& \mathrm{t}_{C}=0.19 ; 356 \mathrm{df} ; \mathrm{x}_{\mathrm{C}}^{2}=1.24 ; 1 \mathrm{df}
\end{aligned}
$$

dividuals with splenomegaly. The statistical analysis was not significant for the remaining groups. 
COSTA, M. F. F. de L. e; ROCHA, R. S. \& KATZ, N. - Splenomegaly in relation to Schistosoma mansoni egg counts: a population based study. Rev. Inst. Med. trop. São Paulo, 28:389.394, 1986.

T A B L E III

Schistosoma mansoni egg counts in individuals with and without splenomegaly, according to four age groups

\begin{tabular}{|c|c|c|c|c|c|c|c|}
\hline \multirow{2}{*}{$\begin{array}{l}\text { Age groups } \\
\text { (years) }\end{array}$} & \multicolumn{3}{|c|}{ Geomotric mean of eggs in individuals } & \multicolumn{4}{|c|}{$\pi / p$ of splenomegaly in individuals } \\
\hline & $\begin{array}{l}\text { without splenomegaly } \\
\text { (n) mean } \pm \mathrm{SD}\end{array}$ & $\begin{array}{l}\text { with } \\
\text { (n) }\end{array}$ & $\begin{array}{l}\text { splenomegaly } \\
\text { mean } \pm \mathrm{SD}\end{array}$ & $\begin{array}{l}\text { with } 12-499 \\
\text { iN.o splen./N. }\end{array}$ & $\begin{array}{l}\text { epg } \\
\text { exam.). }\end{array}$ & $\begin{array}{l}\text { with } \rightleftharpoons \\
\text { (N. }{ }^{\circ} \text { splen./N }\end{array}$ & $\begin{array}{l}500 \mathrm{epg} \\
1.0 \text { exam. }\end{array}$ \\
\hline A. $5-8$ & (135) $356.2 \pm 5.2$ & (10) & $947.2 \pm 4.8^{*}$ & $(3 / 79)$ & 3,8 & $(7 / 66)$ & 10.6 \\
\hline B. $9-12$ & (150) $486.3 \pm 4.5$ & (12) & $522.4 \pm 4.9$ & $(6 / 82)$ & 7.3 & $(6 / 80)$ & 7.5 \\
\hline C. $13-16$ & (138) $519.4 \pm 5.0$ & (13) & $477.4 \pm 3.8$ & $(8 / 71)$ & 11.3 & $(5 / 80)$ & 6.3 \\
\hline D. $\Longrightarrow 17$ & (286) $226.2 \pm 3.5$ & (18) & $253.8 \pm 4.3$ & $(12 / 206)$ & 5.8 & $(6 / 98)$ & 6.1 \\
\hline
\end{tabular}

$\begin{array}{lll}\mathrm{t}_{\mathrm{A}}=1.89 ; 143 \text { df* } ; & \mathrm{x}_{\mathrm{A}}^{2}=1.65 ; \text { ldf } \\ { }_{\mathrm{t}}=0.15 ; 160 \mathrm{df}(\mathrm{NS}) ; & \mathrm{x}_{\mathrm{B}}^{2}=0.07 ; 1 \mathrm{df} \\ { }_{\mathrm{t}}=0.21 ; 149 & \mathrm{df}(\mathrm{NS}) ; & \mathrm{x}_{\mathrm{C}}^{2}=0.65 ; 1 \mathrm{df} \\ { }_{\mathrm{t}}=0.33 ; 304 \mathrm{df}(\mathrm{NS}) ; & \mathrm{x}_{\mathrm{D}}^{2}=0.02 ; 1 \mathrm{df}\end{array}$

dividuals with splenomegaly was higher than the one obtained in the controls.

COOK et al. 5 , surveying hospitalized children from endemic areas in St. Lucia, verified that their 5 cases of splenomegaly were among those that presented higher egg count in the feces. In the U.S.A., WARREN et al.24 and GREMILLION et al ${ }^{12}$, surveying migrants from endemic zones, did not observe important differences in the egg counts between those who presented or not splenomegaly. Similar data 'were obtained by FERREIRA et al. It in Brazilian hospitalized patients. In Sudan, SALIH et al. ${ }^{20}$, also analysing hospitalized individuals, concluded that most patients with splenomegaly presented higher $\mathbf{S}$. mansoni egg counts in the stools.

In the present investigation we studied the ecological and individual levels of egg counts in relation to splenomegaly in different age groups. In relation to the ecological analysis (TABLE 1 and Fig. 1), our findings showed that there was a clearly correspondence between higher mean egg counts and higher percentages of splenomegaly in the age groups 5-9 and 10.14 years, but not in the older ones. An other strikin aspect is that in the central area there was a deviation to the right of the percentage of splenomegaly in different age groups when com. pared to the environs.

It was showed in a previous paper 9 that the percentage of splenomegaly and the geometric mean of $\mathbf{S}$. mansoni eggs had decreased 
COSTA, M. F. F. de L. e; ROCHA, R. S. \& KATZ, N. - Splenomegaly in relation to Schistosoma mansoni egg counts: a population based study. Rev. Inst. Med. trop. Sāo Paulo, \&8:389 394, 1986.

in the center of Comercinho, while in the en. virons they did not change within an interval of seven years. In this way, the ecological data of the present study suggest that: (a) the geometric mean of the number of eggs in the age group 5-14 may be an indicator of the severity of schistosomiasis; (b) the deviation to the proportion of splenomegaly may be an indicator of the decrease of the severity of schistosomiasis in an endemic area.

In relation to the individual analysis, it was found that only in the youngest individuals (5-8 or 5-9 years of age) the splenomegaly was related with higher mean egg counts in the feces, having been a premature tendency to the decrease of excretion of eggs in the patients with splenomegaly when compared to the controls. In fact, the mean of $\mathbf{S}$. mansoni eggs in individuals with splenomegaly decreased in the age groups 9-12 or 10-14, while in those without splenomegaly the decrease of the egg counts was observed only in the oldest individuals ( 15 or $\supseteq 17$ years of age) (TABLES II and III)

CHEEVER ${ }^{3}$ verified through necropsies that there was an apparent reduction in the number of eggs per worm pair in the feces of cadavers with Symmer's fibrosis, when compared to the "asymptomatic" cases. COSTA et al.8 found out a relative diminution of the egg excretion in children that developed splenomegaly, when compared to those that remained without splenomegaly within a seven year interval. The results of the present study are consistent with these observations and suggest that the ecological data are better indicator of the severity of schistosomiasis in endemic areas, as the decrease of the $\mathbf{S}$. mansoni egg counts in the feces of patients with splenomegaly may be a confounding variable for the individual analysis.

\section{RESUMO}

Eșplenomegalia em relação à contagem de ovos de Schistosoma mansoni: um estudo de população

Um estudo seccional da esquistossomose foi realizado em Comercinho, cidade de 1474 habitantes situada no Estado de Minas Gerais (Brasil). Foram feitos exames de fezes pelo método de Kato-Katz e exame clínico em, res- pectivamente, $90 \%$ da população e em $84 \%$ dos indivíduos com mais de 2 anos de idade. As análises de correlação ecológica e de características individuais (caso-controle) foram usadas para investigar a relação entre a presença de esplenomegalia e a "intensidade" da infec. ção pelo S. mansoni em diferentes faixas etárias. $\mathrm{Na}$ análise ecológica observou-se uma ni. tida correspondência entre maior média geométrica de ovos e maior índice de esplenomegalia nas faixas etárias de 5-9 e 10-14 anos. No estudo de características individuais verificouse que só nos indivíduos mais jovens (5-8 ou 5.9 anos) havia maior média de ovos entre os que apresentavam esplenomegalia, sendo que os' pacientes com esplenomegalia apresentaram uma tendência para diminuir a sua eliminação de ovos nas fezes quando a idade aumentou. Isto sugere que os resultados obtidos através da análise ecológica são melhores inđicađores da gravidade da esquistossomose em zonas endêmicas, uma vez que a redução do número de ovos nas fezes dos pacientes com esplenomegalia pode distorcer os resultados obtidos em estudos de caso-controle ou de característi. cas individoais.

\section{ACKNOWLEDGMENTS}

The authors thank to Mr. Gercy de Souza Morais, Mr. Pedro Coura and Mr. José Ribeiro for their technical assistance, and to Prof. Lais de Lima e Costa Araújo, for reviewing the ma. nuscript.

\section{REFERENCES}

1. BARBOSA, F. S. - Morbidade da esuisitossomose Rev. Bras. Malar., 18 (n.o esp.): 3-159, 1966.

2. BARRETO, M. L.; LOUREIRO, S.; MELO, A. S. \& ANJOS, C. F. D. - The effect of Schistosoma mansoni infection on child morbidity in the State in Babia, Brazil. II. Analysis at individual 1evel, Rev. Inst. Med. trop. S. Paulo, 27: 167-171, 1985.

3. CHEEVER, A. W. - A quantitative post-morten study of schistosomfasis mansoni in man. Amer. J. trop. Med. Kyyg., 17: 38-60, 1968.

4. CONCEICYAO, M. J. - Morbidade da esquistossomose mansoni em uma comunidade rural de Mfnas Gerals. Rio de Janeiro, 1976. (Thesis of master - Universidade Federal do Rio de Janeiro).

5. COOK, J. A. BAKER, S. T.; WARREN, K. S. \& JORDAN, P. - A controlled study of morbidity frons schistosomiasis mansoni in St. Iucian chitdren, based on quantitative egg excretion. Amer. J. trop. Med. Hyg., 23: 625.633, 1974. 
COSTA, M. F. F. de L. e; ROCHA, R. S. \& KATZ, N. - Splenomegaly in relation to Schistosoma mansoni egg counts: a population based study. Rev. Inst. Med. trop. São Paulo, 28:389-394, 1986.

6. COSTA, M. F. F. L.; ROCHA, R. S. \& KATZ, N. Morbidade da esquistossomose e sua relaçāo com a contagem de ovos de Schistosoma mansoni em uma zona hiperendêmica do Estado de Minas Gerais. Rev. Inst. Med. trop. S. Paulo, 27: 66-75, 1985.

7. COSTA, M. F. F. I.; ROCHA, R. S.; MAGALHAES, M. H. A. \& KATZ, N. - A clinico-epidemiological sur. vey of schistosomiasis mansoni in a hyperendemic area In Minas Gerais State (Comercinho, Brazil). I. Differences in the manifestations of schistosomiasis in the town centre and in the environs. Trans. roy. Soc. trop. Med. Hyg., 79: 539-545, 1985.

8. COSTA, M. F. F. L.; ROCHA, R. S.; ZICKER, F. \& KATZ, N. - Schistosomiasis clinical evolution in rela. tion to the Schistosoma mansoni egg count in a Bra. zilian endemic area. Trans, roy. Soc. trop. Med. Hyg, 79: 560,1985 .

9. COSTA, M. F. F. L.; ROCHA, R. S.; ZICKER, F. \& KATZ, N. - Evolution of schistosomiasis in an bype. rendemic area of the Minas Gerais State: two cross. sectional studies. Rev. Inst. Med. trop. S. Paulo, 27: $279-285,1985$.

10. COSTA, M. F. F. L.; MAGALHAES, M. H. A.; ROCHA, R. S.; ANTUNES, C. M. F. \& KATZ, N. - Water contact and socio-economic variables in the epidemio. logy of schistosomiasis mansoni in a Brazilian endemic area. Bult. Wld, HIth. Org. (in press)

11. FERREIRA, L. F.; COUTINHO, S. G.; ARGENTO, C. A.; ANDRADE, C. M.; RUBENS, J.; VALENTE, P. \& SILVA, J. R. - O diagnóstico parasitológico na esquistossomose mansoni; estudo comparativo entre o exame de fezes, a biopsia retal e a biopsia hepática. Hospital, (Rio de J.), 69; 93-106, 1966.

12. GREMILLION, D. H.; GECKLER, R. W.; KUNTZ, R. E. \& MARRARO, R. V. - Schistosomiasis in Saudi Arabian recruits; a morbidity study based on quantitative egg excretion. Amer. J. trop. Med. Hyg, 27: 924-927, 1978.

13. GUIMARÃES, M. D. C. - A schistosomiasis mansoni clinico-epidemiologic study in a small Braxilian community. Jerusalém, 1982. (Thesis of master - Hebrew University).

14. ISATZ, N.; CHAVES, A. \& PELLEGRINO, J. - A simple device for quantitative stool thick-smear technique in schistosomiasis mansoni, Rev. Inst. Med. trop. S. Paulo, 14: 397-400, 1972.
15. KATZ, N. \& ZICKER, F. - Correlation between symptomatology and intensity of Schistosoma mansòni ir. fection in inhabitants from endemic areas in Minas Gerais State, Brazil. Bras, méd., 11: 55-59, 1975.

16. KLOETZEL, K. - Splenomegaly in schistosomiasis mansoni. Amer. J. trop. Med. Hyg., 11: 472-476, 1962.

17. LEHMAN Jr., J. S.; MOTT, K. E.; MORROW Jr., $\mathbb{R}$. H.; MUNIZ, T. M. \& BOYER, M. H. - The intensity and effects of infections with Schistosoma mansoni in a small community in northeast Brazil. Amer. $y$. trop. Med. Hyg., 25: 285-294, 1976.

18. ONGOM, V. L. \& BRADLEY, D, I. - The epidemii. logy and consequences of Schistosoma mansoni inf $\mathrm{S}: \mathrm{O}$ tion in the West Nile, Uganda. I. field studies of cornmunity at Panyagoro. Trans. roy. Soc. trop. Hyg., 66: 835-851, 1972.

19. PELLEGRINO, J. \& MEMORIA, J. M. P. - A reaçăo intradérmica na esquistossomose mansoni. III. Influén. cia da idade, sexo, cor e local da reação, Rev. Inst. Med. Trop. S. Paulo, 2: 218-223, 1960.

20. SALIH, S. Y.; MARSHALL, T. F. \& RADALOWICZ, A. - Morbidity in relation to the clinical forms and to intensity of infection in Sehistosoma mansoni in the Sudan. Ann. trop. Med. Parasit., 73: 439-449, 1979.

21. SIONGOK, T, K. A.; MAHMOUD, A. A. F.; OUMA, J. H.; WARREN, K. S.; MULLER, A. S.; HANDA, A. K. \& HOUSER, H. B. - Morbidity in schistosomiasis mansoni in relation to intensity of infection; study of a community in Machakos, Kenya. Amer. J. trop. Med. Hyg., 25: 273-284, 1976.

22. SMITH, D. H.: WARREN, K. S. \& MAHMOUD, A. A. F. - Morbidity in schistosomiasis mansoni in relation to intensity of infection; study of a community in Kisumi, Kenya. Amer. J. trop. Med. Hyg., 28: 220-229, I979.

23. SNEDECOR, G. W. \& COCHRAN, W. G. - Statistical methods. 6th.ed. Iowa, Iowa University Press, 1977

24. WARREN, K. S.; MAHMOUD, A. A. F.; CUMMINGS, P.: MURPHY, D. J. \& HOUSER, H. B. - Schistoso miasis mansoni in Yemeni in California; duration of infection, presence of disease, therapeutic management Amer. J. trop. Med. Hyg., 23: 902-909, 1974.

Recebido para publicaçäo em 25/11/1985. 